Іващенко А. М. к.т.н., доцент;

Павліковський А. К. к.військ.н., доцент;

Сівоха I. M.

Центр воєнно-стратегічних досліджень Національного університету оборони України імені Івана Черняхівського, Київ

\title{
Концепція оборонного планування на основі розвитку спроможностей: проблеми впровадження
}

Резюме. Проводиться огляд концепції оборонного планування на основі розвитку спроможностей, який вже став “золотим” стандартом оборонного планування в різних країнах та аналізуються проблеми його впровадження в секторі безпеки і оборони України.

Ключові слова: оборонне планування, спроможності.

Постановка проблеми. Впровадження нової концепції оборонного планування на основі спроможностей зіткнулося 3 цілою низкою проблем і виявилося досить складною в сприйнятті. Стала проблема: якщо основоположні принципи вірно передають сутність нової концепції планування, чому виникли розбіжності в середовищі експертів 3 оборонного планування i керівників різного рівня, а впровадження системи в практику роботи органів військового управління відбувається важко і неоднозначно? Деякі 3 проблем впровадження виявилися незначними i були зняті шляхом консультацій. Інші носять системний характер і потребували підвищеної уваги 3 боку всіх учасників процесу стратегічного планування. проблем.

Дана стаття направлена на розгляд цих

Аналіз основних досліджень i публікацій. Зміна парадигми оборонного планування - відмова від концепції, яка в якості вихідних даних розглядає загрози національним інтересам i перехід до концепції, що базується на спроможностях сил оборони (Capability - Based Defence Planning - CBDP) вперше була анонсована у "Чотирьохрічному оборонному огляді збройних сил США” 2001 року: “...треба визначити, які спроможності необхідні збройним силам для стримування і нанесення поразки противникам США, які будуть робити ставку на раптовість, обман i асиметричні засоби ведення війни" [1].

Для впровадження CBDP почали активно розроблятися нові засади, принципи i моделі [2-4].

Так, вже у 2002 році 3'являються теоретичні засади функціонування CBDP, розроблені RAND corporation [2].
У січні 2004 року впливова дослідна група під керівництвом заступника міністра оборони США Едварта Олдріджа (Edwart Aldridge) завершує розробку засад впровадження CBDP в діяльність міністерства оборони США. Підсумковий звіт дослідної групи [3], більше відомий як "Aldridge Study" дає визначення CBDP, мети та алгоритму впровадження, вводить ряд нових фундаментальних понять, таких як сфери спроможностей (Joint Capability Areas - JCA), система інтеграції та розвитку спроможностей (Joint Capabilities Integration and Development System - JCIDS) [4]. Дослідження пропонує новий спільний лексикон політиків i військових, який дозволяє чітко визначати сфери і обмеження майбутніх воєнних місій i ефективно управляти ресурсами[5-6].

"Керівництво по стратегічному плануванню” 2004 року [7] остаточно затвердило перехід міністерства оборони США на систему планування розвитку збройних сил на основі спроможностей. На основі цього керівництва були внесені значні зміни в основні складові стратегічного планування розвитку 3С: систему інтеграції і розвитку об'єднаних спроможностей та систему прийняття рішень на придбання озброєння i військової техніки. Розроблений "Каталог об'єднаних спроможностей”[8], став загальною базою вихідних даних для всіх ЗС США. 3 метою впровадження CBDP штаби видів ЗС внесли зміни в організаційно-штатні структури, методи і порядок своєї роботи [9].

До впровадження нової концепції оборонного планування приєдналися ЄС [10], HATO [11-12] та ряд інших країн[13-14]. У 2011 році ця концепція отримала назву “золотого стандарту оборонного планування" [15]. 
Метою статті $є$ узагальнення та аналіз проблем впровадження концепції оборонного планування на основі спроможностей.

Виклад основного матеріалу Стратегічний оборонний бюлетень України 2016p. [16] передбачає розвиток системи оборонного планування як складової національної системи планування у секторі безпеки і оборони на основі впровадження сучасних методів, зокрема, планування на основі спроможностей (рис. 1).

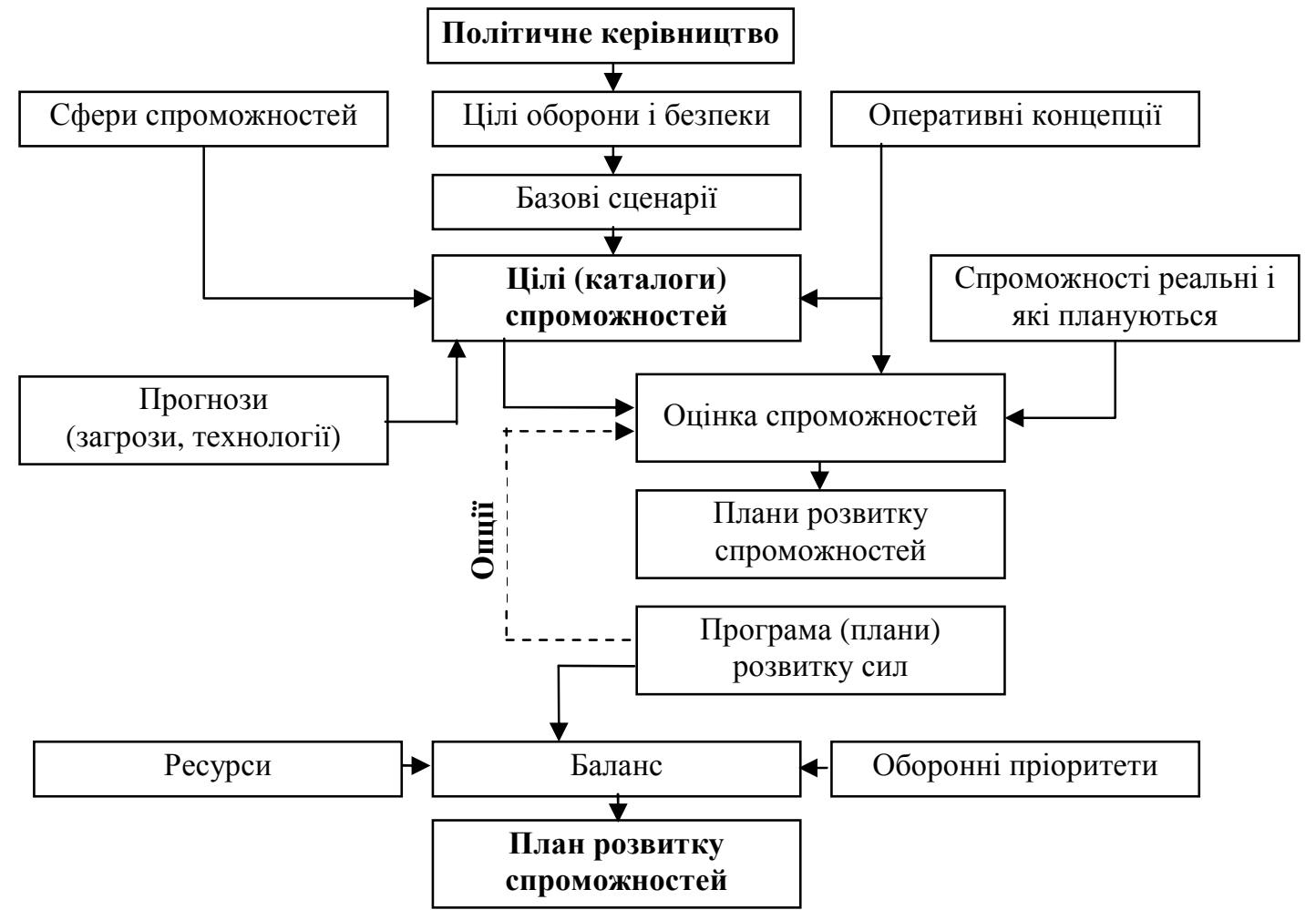

Рис. 1 Загальний алгоритм процесу оборонного планування на основі розвитку спроможностей

Ці зусилля дозволять отримати наступні основні результати:

розширити перелік завдань сил безпеки і оборони, в першу чергу в умовах особливого періоду мирного часу;

підвищити ефективність діяльності сектора безпеки i оборони, що полягає не просто в зміні їх структури, бойового складу тощо, а в зменшенні ризиків для безпеки країни;

оптимізувати ресурсні витрати, в першу чергу за рахунок досягнення прозорості при закупівлі озброєння і військової техніки.

Нова концепція суттєво впливає як на систему оборонного планування розвитку збройних сил (3С), так і всю систему прийняття воєнно-політичних рішень. Першим стає питання, як противник буде вести бойові дії, а не визначення ймовірного противника та напрямку, з якого розпочнеться вторгнення.

Розглянемо основні проблеми впровадження нової концепції оборонного планування.

1. Термінологія. Англійський слово "capability" має два основних значення в українській мові - можливості(спроможності) і потенціал.

Поняття “спроможності” (capability) використовується для визначення різних процесів:

мети і завдань оборонного планування,

сил i засобів, які можуть виконати поставлені завдання;

органів і посадових осіб, які беруть участь в розробці концепцій.

Будь-який 3 цих процесів вимагає визначення своїх специфічних спроможностей.

МО США запровадило універсальне визначення “спроможностей” [8]: спроможності - ие “здатність по досягненню необхідного результату, визначеного критеріями та умовами, за допомогою комбінації сил $i$ засобів, а також методів $i$ способів їх застосування для виконання поставлених завдань". Дослідна група Олдріджа (Aldridge Study) центральне місце приділяе уточненню i формулюванню "спроможностей” як основи всієї перспективної системи оборонного планування [3]. Національна нормативно-правова база i спеціальна література не дають однозначного i чіткого визначення цього поняття. 
2. Правильне розуміння засад нової концепції оборонного планування. Підходи до оборонного планування періоду холодної війни забезпечували підтримку стабільності, рівновагу в політичній сфері і паритет воєнної могутності країн. Перехід від стратегічних цілей планування до структури військ уявляв собою досить складний, але добре відпрацьований процес, зрозумілий фахівцям 3 оборонного планування. 3 крахом біполярної системи міжнародних відносин відродження надійного методу розподілу наявних ресурсів для вирішення нових завдань стало логічним.

Перший 3 цих напрямків став новаторським для фахівців 3 оборонного планування. Другий був закладений ще на початку 1960-х років в рамках системи програмно-цільового планування. Однак складність i невизначеність військовополітичної обстановки (ВПО), руйнування систем глобальної та регіональної безпеки та інші гібридні фактори вдихнули нове життя в цю тривіальну ідею.

Проблема зародилися відразу після декларації переходу на новий метод оборонного планування, в тому числі 3-за поверхневого або навіть помилкового трактування іï основних положень. Вочевидь, плутанина буде тільки зміцнюватися, що особливо наочно проявляється у взаємодії підходів до системи планування "від загроз" і “від можливостей”.

3. Зміна підходів до прогнозування ВПО $\boldsymbol{i}$ розробки базових сценаріїв. Так, наприклад, у ряді документів заявляється, що нова система замінюе раніше діючу систему оборонного планування на основі загроз. Вивчення CBDP спростовує подібну точку зору. Це стосується всіх елементів планування, в тому числі і такої важливої складової системи планування “від загроз”, як базові сценарії. Якщо у теперішній час ВПО і менш передбачувана, ніж в попередні роки, то 3 цього не випливає, що базові сценарії не можуть бути використані при новому підході. 3 цього тільки випливає, що набір сценаріїв, який існував раніше, повинен бути істотно розширений і доопрацьований, в тому числі 3 урахуванням того, що специфічні варіанти нейтралізації загроз не повинні підміняти систему планування на основі спроможностей, а працюючи 3 нею в тісній взаємодії, сприяти формуванню нових вимог до розвитку сектора безпеки і оборони. При цьому Сили безпеки i оборони повинні вирішувати значно більший обсяг завдань у будь-яких умовах і в будь-якій обстановці.
Необхідність адаптаиії старих аналітичних підходів до СВDP $i$ збільшення кількості завдань вимагає переглянути категорії “кількість" $i$ "якість" в системі оборонного планування. Фактор невизначеності розвитку ВПО змушує збільшити число розроблюваних сценаріїв і більш ретельно ї опрацювати 3 точки зору підвищення складності та варіабельності. Впровадження принципу “об'єднаності” в процес планування також вимагає збільшити кількість оцінюваних параметрів спроможностей $i$ засобів для вирімення завдань. Все це в сукупності вимагає змінити підходи до якості аналітичних розробок і підвищити вимоги до аналізу ВПО і прогнозування іiі розвитку, як найважливішої складової стратегічного планування розвитку сектора безпеки і оборони.

\section{4. Використання категорії “ризик” в} якості основної оцінки ефективності планування. У будь-якій системі повинні бути закладені оціночні показники їі діяльності. Що ж може бути кінцевою продукцією функціонування сектора безпеки і оборони? 3 одного боку, внесок сектора в забезпечення безпеки різноманітний, складний i носить комплексний характер, щоб урізати його до декількох показників. 3 іншого - складність і комплексність функціонування сектору проявляється в ході прийняття важливих військово-політичних рішень. Але у всіх документах $\epsilon$ один показник, на який посилаються фахівці з оборонного планування, використовуючи його як ключ до правильного вибору рішення серед можливих альтернативних стратегічних варіантів, - це ризик. Наскільки стратегічне планування розвитку бізнесу полягає, як правило, в збільшенні прибутку, настільки і стратегія національної безпеки країни повинна передбачати істотне зменшення ризику.

\section{5. Розробка методів, моделей $i$} методології нової системи оборонного планування. Традиційні моделі воєнних конфліктів, спрямовані на знищення потенційних супротивників 3 повним напруженням усіх наявних людських i матеріальних ресурсів, поступово відходять на другий план в системі стратегічного планування. Актуальними стають гібридні сценарії із залученням всього спектру як національної могутності, так і союзників, в яких ЗС відводиться суттєва, але не головна роль. Одночасно спостерігається значне підвищення складності досліджень міждержавного протиборства, що в сукупності вимагає розробки і впровадження 
нових аналітичних методів в систему стратегічного планування розвитку сектора безпеки $і$ оборони, які раніше застосовувалися тільки в невійськових галузях розвитку держави.

Методики оцінки ефективності бойових дій i суто технічних систем добре відпрацьовані і зрозумілі військовим експертам. Всі вони в сукупності є хорошою вихідною базою для оцінки конкретних зразків озброєння і військової техніки (OBT) i дозволяють зробити обгрунтований вибір. На оперативному рівні порівняння відносної ефективності альтернативних пакетів військ (сил) при вирішенні поставлених завдань $€$ достатньо складним і трудомістким. Саме для подібного порівняння в використовується категорія “ризик”, як оцінка впливу прийнятих управлінських рішень на безпеку всієї нації і держави.

В CBDP встановлено вимогу оцінки ризиків як найважливішої оцінки ефективності розвитку сектора безпеки i оборони, а Генеральний штаб повинен проводити оцінку ризику для всіх оперативних планів. Подібна оцінка, особливо на вищому (стратегічному) рівні, залишається досить непередбачуваним i, по суті, недосконалим процесом. Потрібні певні зусилля для розвитку загальної структури оцінки наявних i особливо майбутніх спроможностей, перетворення категорії “ризик” в найважливіший показник оцінки ефективності стратегічного планування.

Складові оборонного потенціалу мають специцфічні можливості, які визначаються певними показниками. Ці показники необхідно розрахувати i інтерпретувати для прийняття рішення. При цьому вхідна інформація за наявними показниками хоча $\mathrm{i}$ може бути виражена у вартісному відношенні, але дуже непросто поєднується 3 вихідними результатами щодо розвитку ЗС. Це серйозна проблема для будь-якої аналітичної структури, особливо 3 урахуванням такого показника, як “вартість-ефективність”.

CBDP вимагає від виконавців розробки декількох варіантів застосування угруповань військ (сил) в різних умовах ВПО. Оцінивши вищесказане, стає зрозуміла глибина проблеми концептуального плану при реалізації нової системи планування.

6. Адитивність до постійного розиирення списку завдань, до виконання яких повинні бути готові сили безпеки $\boldsymbol{i}$ оборони. Після анексії Криму і вторгнення 3С Росії в східні райони України була визнана необхідність адаптації ЗС України до вирімення завдань в особливих умовах мирного часу, як виявилося, не менш важливих для національної безпеки країни, ніж перемога в можливих, але не обов'язково традиційних воєнних операціях. Крім того, були виявлені серйозні проблеми захисту національної території i елементів критичної інфраструктури.

Антитерористична операція на сході України сформувала нове бачення вигляду перспективної системи національної безпеки [17]. Основна діяльність сектору безпеки i оборони України все більше зміщується на ліквідацію гібридних, асиметричних, неявних i несподіваних загроз існуванню України. В результаті виникла необхідність вирішення більшого обсягу завдань, ніж в небезпечний, але набагато більш прогнозований період становлення української держави. Але головне тут не в збільшенні кількості завдань, а в їх вирішенні, яке лежить найчастіше в стороні від традиційного і зрозумілого (для певної частини населення) застосування воєнної сили. У подібній ситуації ЗС повинні мати необхідну гнучкість і адаптивність органів оборонного планування, щоб їх реакція відповідала будьяким можливим змінам ВПО.

7. Сумісність 3 діючими оборонними програмами, неправильне розуміння суті управління новою системою, в першу чергу щодо вихідної бази даних i отриманих результатів в частині розвитку оборонного потенціалу і застосування військ.

Квінтесенція нового підходу полягає в тому, що спочатку військові потреби повинні ідентифікуватися в термінах головних завдань сектора безпеки i оборони i встановлених стандартів їх виконання і тільки після цього в термінах альтернативних комбінацій необхідних для виконання поставлених завдань ресурсів. Одночасно важливо зрозуміти, що спроможності не можуть бути визначені $i$ оцінені надто загально або невизначено, наділені надмірною гнучкістю, щу вимагається для виконання в запропонованій конфігураиії будь-яких, в тому числі не пов'язаних між собою завдань.

8. Дотримання вимоги “об'єднаності" сил безпеки і оборони на будь-якому етапі планування. Світовий досвід оборонного планування за останні 25 років $є$ історією просування в життя концепції створення посправжньому об'єднаних сил безпеки і оборони. Концепція CBDP надає додаткові можливості для досягнення цієї найважливішої мети. Необхідна розробка і просування офіційно прийнятих сценаріїв розвитку ВПО на 
перспективу і ведення відповідної бази даних. База сценаріїв повинна бути єдиною i обов'язковою для всіх структур сектора безпеки i оборони i не допускати несанкціонованих змін. Органи військового управління повинні зосереджуватися на вирішенні інших, більш важливих питань, а не на проведенні непотрібних дебатів і суперечок за варіантами сценаріїв.

\section{9. Визначення}

відповідно до

спроможностей “мережецентрічності” - ключовий принцип, що припускає необхідність враховувати сукупні зусилля формувань і засобів збройної боротьби під час вирішення завдань. На перший план виходить не ТTХ окремих зразків і систем ОВТ, а здатність Сил безпеки i оборони до проведення “об'єднаних" операцій.

Досвід розвитку кризових ситуацій показує, що найкраще вирішення проблем не завжди залежить від потужності двигунів бойових машин, більшої чи меншою ймовірності ураження об'єктів, пропускної здатності або діапазону мереж зв'язку. Можливості Сил безпеки і оборони все в більшій мірі обумовлюються наявністю інноваційних концепцій ведення операцій, впровадженням нових форм i методів навчання особового складу і формуванням у командирів необхідних навичок управлінської діяльності, в тому числі 3 використанням бізнес-процесів. Раніше в рамках процесу оборонного планування на подібні нюанси фахівцями практично не зверталося уваги. В концепції CBDP нематеріальні фактори стали ще одним елементом, для обліку та оцінки якого в обов'язковому порядку повинні залучатися досвідчені експерти.

10. Посднання в процесі планування розвитку спроможннотей на середньо- $i$ довгострокову перспективи та поточних потреб сил безпеки $\boldsymbol{i}$ оборони. Крім відмінностей організаційного, методичного, технологічного плану, та й самої культури довгострокового i поточного планування, можна виділити ще одне ключове відмінність складових в загальній системі стратегічного планування будівництва ЗС. Ця різниця полягає в головному кінцевому результаті роботи системи.

\section{1. Формування}

необхідного переліку(каталогу) спроможностей сектора безпеки $i$ оборони за прогнозними варіантами. Проблема впровадження CBDP полягає не тільки в необхідності вироблення окремих переліків спроможностей для різних прогнозних горизонтів (які часто будуть кардинально відрізнятися один від одного), але i в застосуванні для цього базових принципів планування. Природно, орієнтованість системи планування від спроможностей на кінцевий результат поширюється як на короткострокове, так $i$ на середньо- $i$ довгострокове планування.

Реалізація принципу постійного розширення списку завдань в рамках існуючих планів представляє значні труднощі для органів військового управління, які несуть відповідальність за вирішення поточних завдань, в яких задіяні тільки доступні спроможності. Іншими словами, CBDP притаманні певні умовності і допущуення, щуо не дозволяють в повній мірі використовувати переваги нового підходу, насамперед для поточного планування.

Рішення даної проблеми можливе за рахунок уточнення термінологічного апарату, розробки нових методичних підходів i прийомів в системі планування, що дозволяють здійснювати тісну координацію виконавців для різних етапів планування.

12. Організаційна проблема є найбільш складною для впровадження CBDP. Справа в існуючій системі прийняття військовополітичних рішень. Воєнно-політичне керівництво формує національну оборонну стратегію (воєнну доктрину), міністерство оборони здійснює стратегічне планування i розробляє оборонний бюджет, генеральний штаб планує і здійснює поточні операції.

Розділення функціональних обов'язків в системі оборонного планування не перешкоджає дотриманню вимог “об'єднаності". Важливість міжвидової взаємодії при формуванні оборонного бюджету очевидна для всіх учасників процесу стратегічного планування. Однак на практиці види постійно займаються відстоюванням своїх інтересів на шкоду загальним завданням. В результаті зняття постійних протиріч в рамках розробки загального бюджету лягає додатковим навантаженням на стратегічне планування.

Концеепиія СВDР вимагає, щзоб переклад стратегіі в військові спроможності проводився в об'єднаному плануючому органі, а всі військові ресурси структурно включені $i$ фінансуються майже повністю за рахунок бюджету.

Висновки. Таким чином, концепція CBDP є черговим етапом розвитку системи стратегічного планування розвитку сектору безпеки i оборони держави. Її впровадження 
вимагає глибокої багатофункціональної реформи, яка охоплює всі засади національної безпеки і оборони. Разом з тим, впровадження CBDP зіткнулася 3 низкою проблем. Частина 3 них може бути знята досить швидко додатковою підготовкою фахівців 3 оборонного планування. Інші проблеми мають системний характер і потребують підвищеної уваги з боку всіх складових сектора безпеки i оборони.

Головне полягає в тому, що впровадження CBDP допоможе військовополітичному керівництву менше думати про управління бюрократичними процесами, а зосередитися на керуванні ризиками, зводячи загрози національній безпеці до мінімуму.

У подальшому будуть розглянуті основні складові процесу оборонного планування на основі розвитку спроможностей.

\section{СПИСОК ВИКОРИСТАНОЇ ЛІТЕРАТУРИ}

1. Quadrennial Defense Review Report. Department of Defense, Washington, D.C., September 2001. p. 14.

2. Davis, Paul K. Analytic Architecture for CapabilitiesBased Planning, Mission-System Analysis, and Transformation. National Defense Research Institute, Santa Monica, USA, 2002

3. Joint Defense Capabilities Study: Improving DoD Strategic Planning, Resourcing, and Execution to Satisfy Joint Requirements. Final Report, Department of Defense, Washington, D.C., January 2004, 127 p.

4. Більш детальну інформацію про JCAs можна знайти в: Bonnet Joe. Joint Capability Areas. Presented of the Deputy Director for Force Development \& Integration Joint Staff J-7 to Future of Precision Strike Conference 23 Jan 08. Joint Staff, 2008, 50 p.

Стаття надійшла до редакції 16.03.2017
5. Joint Capability Areas. Difinition. Joint Staff, Washington, Approved as of 12 January 2009. - $52 \mathrm{p}$.

6. Department of Defense. Dictionary of Military and Associated Terms. Joint Publication 1-02, DoD, 17 March 2009.

7. Strategic Planning Guidance, Secretary of Defense Donald Rumsfeld, Washington, Department of Defense. 2004

8. Manual for the Operation of the Joint Capabilities Integration and Development System (JCIDS). \# 3170.01I. 12 February 2015. Joint Staff, 2015, 416 p.

9. Naval Analytical Capabilities: Improving CapabilitiesBased Planning. Naval Studies Board. Division on Engineering and Physical Sciences Washington, DC: The National Academies Press, 2005.

10. European Union. European Security and Defence Policy. Executive Summary. Development of European Military Capabilities. June 2009. 9 p.

11. NATO Research and Technology Board: Panel On Studies, Analysis and Simulation (SAS), Handbook in Long Term Defense Planning, 2001.

12. NATO, The Use Of Scenarios In Long Term Defense Planning http://www.plausiblefutures.com/55074

13. Defence Capability Guide 2012. Annual Report. Australian Government. Department of Defence. 48 p.

14. Anastasios Papazoglou. Capability-Based Planning with Togaf and Archimate. Master Thesis. Bizz Design, University of Twenty, $2014154 \mathrm{p}$.

15. De Spiegeleire Cf. Stephan. Ten Trends in Capability Planning for Defence and Security. The Royal United Services Institution (RUSI) Journal, v. 156 \#5, 2011, pp. 2028

16. Стратегічний оборонний бюлетень України. Указ Президента України від 6 червня 2016 року № 240/2016. Стратегічна ціль 2. Ефективна політика, системи планування і управління ресурсами в секторі оборони 3 використанням сучасних євроатлантичних підходів

17. Концепція розвитку сектору безпеки i оборони України. Указ Президента України від 14 березня 2016 року № 92/2016

Иващенко А. М. к.т.н., доцент;

Павликовский А. К. к.воен.н., доцент;

Сивоха И. М.

Центр военно-стратегических исследований Национального университета обороны Украины имени Ивана Черняховского, Киев внедрения

Концепция оборонного планирования на основе развития возможностей: проблемы

Резюме. Проведён обзор концепции оборонного планирования на основе развития возможностей, которое уже стало “золотым” стандартом оборонного планирования в разных странах. Проанализированы проблемы его внедрения в секторе безопасности и обороны Украины.

Ключевые слова: оборонное планирование, возможности.

\section{A. Ivashchenko, Ph.D;}

A. Pavlikovsky, Ph.D;

I. Sivoha

Center for Military and Strategic Studies National Defence University of Ukraine named after Ivan Chernyhovsky, Kyiv

Conception of the defensive planning on the basis of development of possibilities: problems of introduction

Resume. The review of conception of the defensive planning is conducted on the basis of development of possibilities, that already became " the gold" standard of the defensive planning in different countries and the problems of his introduction are analysed in the sector of safety and defensive of Ukraine.

Keywords: defensive planning, possibilities. 